\section{Implications for Asia}

How does all of this relate to Singapore and to Asia? It takes more than central planning and government funding to ensure a successful academic and high-tech future. $\mathrm{Ku}-$ wait has for several decades invested heavily in higher education, building an effective but hardly world-class or research-based university. A tradition of academic excellence is important, as is an environment of academic and intellectual freedom. Scholars work best in an atmosphere of freedom. Size is important, too. Small academic communities can be quite good, even world-class, but can seldom achieve the highest academic pinnacles. Take Sweden or Denmark as examples.

\section{It takes more than central planning and government funding to ensure a suc- cessful academic and high-tech future.}

An environment that encourages but does not dictate university development or academe's relations with industry and government has been key to Boston's academic strength. Diversification is important, too. Not all postsecondary institutions can be Harvard or MIT. There is room for different kinds of schools, with different aims, patterns of funding, varying quality. A mix of public and private initiative helps as well, providing more avenues for funding and greater possibilities for diversity and the cre- ation of niches. The possibility of failure provides an added incentive.

Most Asian countries cannot aspire to excellence in all fields of knowledge. Choices need to be made, and here a combination of academic, public, and private decision makers may be the most effective way to determine higher education policy. A fine balance of institutional autonomy and a sense of the broader public interest is necessary for academic planning.

Singapore's aspiration to become the "Boston of Asia" will not be so easy. Boston, after all, started its academic quest in 1636. And the structural problems are formidable. Some, such as commitments to academic freedom and diversification, are attainable. Others, such as size, are more difficult, although regional consortia may be a partial answer. Singapore's substantial investments in higher education, its stress on internationalization, its growing links to some of the world's most prestigious universities, and its targeted research and training strategy all contribute to building a world-class academic system.

As Singapore, and Asia, think through strategies for participation in the knowledge economies of the $21^{\text {st }}$ century, realistic approaches to higher education development are necessary. Universities are central contributors to a knowledge economy, providing both the trained personnel and the research that is necessary. Yet, universities cannot be bought "off the shelf." They require both freedom and resources. They are at the same time national and international institutions, linked to local realities as well as to the wider world of research. They require freedom to flourish, and yet must serve the public interest.

\title{
Financing Higher Education in the United States: An Overview
}

\section{Thomas R. Wolanin}

Thomas $R$. Wolanin is research professor of education policy and of political science, George Washington University, 2134 G St., NW, Washington, DC 20052. E-mail: <wolanin@gwu.edu>.

$\mathrm{T}$ he most significant distinction in revenue sources for the 3,600 nonprofit institutions of higher education in the United States is between public institutions governed by one of the 50 states and private institutions governed by private boards of trustees.

\section{Sources of Revenue}

Tuition payments account for only 19 percent of the revenue for public institutions, but they make up 42 percent of the revenue-the largest single source-for private institutions. Tuition is a smaller but still significant part of the revenue for public institutions. In contrast to many nations, all public and private institutions of higher education in the United States charge tuition.
State government is the source of 36 percent of the revenue for public institutions but only 2 percent of that for private institutions. Revenue from state government is the largest single source of revenue for public institutions, which receive block grants for core functions such as their instructional program. The small portion of their revenue (2 percent) that private institutions receive from state government is usually in the form of grants or contracts awarded competitively for a specific purpose, such as a special research or training project. The states generally do not supply any general operating funds for private institutions.

Local government is a minor source of funding for both public (4 percent) and private (1 percent) institutions. However, the revenue to public institutions from local governments usually consists of operating funds for local public institutions, typically two-year community colleges. The revenue to private institutions from local governments is 
again in the form of competitive grants or contracts for specific purposes.

The federal government provides a significant share of the revenue for both public (11 percent) and private (14 percent) institutions. For both types of institution, these federal revenues come in the form of competitive grants or contracts.

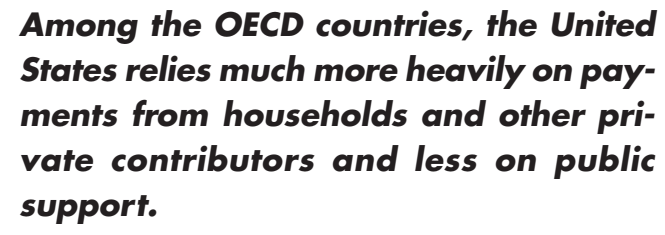

Private sources provide 4 percent of the revenue for public institutions but more than twice as much (10 percent) for private institutions. The major private sources are individuals (frequently the alumni of an institution), business, and philanthropic foundations.

Endowment income is the source of 5 percent of the revenue for private institutions but just 1 percent of the revenue for public institutions. Typically, donations from private sources (individuals, business, and foundations) to the endowment trust are invested, and the annual income is used by the institution for operating expenses or other purposes. In effect, endowment income is another form of revenue from private sources. Combining the revenue from private sources with that from endowment income, private institutions receive a significant 15 percent of their revenue from these sources. Even public institutions get 5 percent of their revenue from such sources.

Sales and services provide an identical 22 percent share of the revenue for both public and private institutions. The main portion of revenue in this category comes from students who pay rent for dormitory rooms or eat in the institution's dining halls or cafeterias.

Finally, to complete this sketch of the sources of revenue of institutions of higher education, we must consider the financial aid provided to students through federal government programs, which totaled $\$ 46$ billion in the 19981999 school year. Students spent much of this \$46 billion on tuition, dormitory, and dining hall charges at institutions of higher education. In other words, some of the revenues in the categories "tuition" and "sales and services" in fact belongs in the category "federal government." Since federal student aid funds are frequently mingled with other student funds, it is not possible to measure exactly how much of federal financial aid becomes revenue at institutions of higher education. In the final analysis, the "federal government" share of the revenues for both public and private institutions would be on the order of 20 to 25 percent.

Clearly, all institutions, both public and private are heavily dependent on their ability to obtain funds from a variety of sources. Institutions must work to attract tuitionpaying and financial-aid-receiving students. Their dormitories and dining halls must compete with the private sector for student-consumer spending. They must vie with other institutions as well as private-sector vendors for grants and contracts from the federal, state, and local governments. They must outdo other worthy causes for the favor of individual, business and foundation donors. Even the state and local support public institutions receive for general operating expenses is subject to competition. The allocation of these funds is usually driven by institutional enrollments. Public institutions must always struggle for more favorable state revenue allocations. The most successful institutions in this effort are the more flexible, dynamic and high-quality ones.

\section{Who Pays?}

Two groups pay for higher education: first, society as a whole (i.e., all taxpayers), which provides support for higher education institutions through public or government programs, and second, the private or nongovernmental sector. Private contributions to higher education can be further divided between those that come from households (i.e., students and their families) and those that come from other private sources such as individual donors, business, and foundations.

\section{Because the benefits of higher educa- tion are both public and private, contri- butions from the two sectors are called on to pay for higher education in the United States and other nations.}

Because the benefits of higher education are both public and private, contributions from the two sectors are called on to pay for higher education in the United States and other nations. There is a very large range in the shares that different countries assign to the public and private sectors. For example, in Korea 84 percent of the total expenditures for higher education come from private payments and only 6 percent from the public sector. In contrast, in Denmark .5 percent of the total expenditures for higher education come from the private sector and 99.5 percent from the public sector. In the United States, 52 percent of the total expenditures for higher education come from private 
payments, which includes 38 percent from households and 14 percent from other private contributors. This level of private payments and household payments is exceeded only by Korea and Japan among OECD (Organisation for Economic Cooperation and Development) industrial or developed countries. The average among OECD countries is 20 percent of total expenditures for higher education from private payments, of which 16 percent is from households. Conversely, among OECD countries the average share of higher education expenditures from public support is 80 percent.

Among the OECD countries, the United States relies much more heavily on payments from households and other private contributors and less on public support. It is also noteworthy, however, that the total expenditures for higher education in the United States as a percentage of gross domestic product is twice the OECD average-2.4 percent in the United States versus an average of 1.2 percent for the OECD countries.

There may be a lesson here. Perhaps a system that balances support for higher education more evenly among the public, households, and other sources in the private sector results in a much higher absolute level of support for higher education. Such an arrangement enables the United States to maintain a more "democratic" higher education sector than other countries, one that encompasses a larger share of the population. For example, 67 percent of those who complete secondary school enroll in higher education in the United States, a rate much higher than in most other nations.

\section{Changes in the Academic Workplace in the United States}

\section{Kerry Ann O'Meara}

Kerry Ann O'Meara is coordinator of the Project on Faculty Appointments, Graduate School of Education, Harvard University, 14 Story St., Cambridge, MA 02138, USA.

$\mathrm{I}_{\mathrm{t}}^{\mathrm{t}}$ tenure is to survive as the standard practice in the United States, traditional policy, as codified by the American Association of University Professors and outlined in the 1990 AAUP Policy Documents and Reports, may have to adapt to changing circumstances in the academic world. In his 1998 American Association for Higher Education (AAHE) New Pathways Series working paper, Ideas in Incubation: Three Possible Modifications to Traditional Tenure Policies, Richard Chait considers three possible modifications to traditional tenure practices: tenure by objectives (a reconfiguration of the probationary period), posttenure reviews that focus more on departments than on individual performance, and guarantees of academic freedom without tenure. These considerations are in keeping with the prevailing public disposition to "mend, not end" tenure.

Tenure by objectives (TBO) seeks to reduce the stress and anxiety of tenure-track faculty experience stemming from ambiguous standards; vague measures of success; and uncertainty about the appropriate mix of teaching, research, and service. The alternative is to base tenure decisions on explicit criteria, performance-based agreements, and demonstrated competence.

How does it work? At the start of a faculty member's first year, the candidate, department chair, and a mentor committee establish a written workplan that describes performance-related goals to be achieved over the course of a probationary period. The plan outlines an appropriate weighting for teaching, research, and service-reflecting the tenure candidate's interests and the department's needs and priorities. The plan also specifies what constitutes appropriate and ample evidence of proficiency in each area of faculty work. Candidates submit a portfolio of work samples to substantiate competency and goal achievement in specific areas of their workplan as part of each annual review. If the department chair and mentor committee or a panel of internal experts are satisfied that competency has been demonstrated in a particular area, the faculty member becomes "certified" in that area and it is no longer at issue for tenure.

TBO might be particularly helpful in the areas of teaching and service, where questions such as "what constitutes good teaching?" and "what kinds of service are most important?" keep candidates guessing in traditional tenure systems. It could also resolve confusion in the research area about the relative importance of quality and quantity, or refereed versus nonrefereed publications, and journal articles versus books or book chapters because the committee's preferences would be carefully laid out in the workplan. Under TBO, candidates would continue in their positions as long as the department observed satisfactory progress toward their objectives. Instances of substantial evidence of inadequate progress would lead to nonreappointment with due notice. An upper limit of 10 years might be advisable, but the process would be driven by results rather than deadlines. Not all members of a cohort would reach the point of tenure at the same time. This option is not unlike doctoral degree programs, which delineate at the outset the requirements for the degreeincluding the specific mix of courses, comprehensive exams, dissertation proposal, and defensible thesis. Students finish when the requirements have been met.

Different components of the TBO system have been piloted in the United States. The Department of Small Animal Medicine and Surgery in the College of Veterinary Medicine at Texas A\&M University assigns a mentor 